\title{
Endophytic Bacteria in Toxic South African Plants: Identification, Phylogeny and Possible Involvement in Gousiekte
}

\author{
Brecht Verstraete ${ }^{1 *}$, Daan Van Elst ${ }^{2}$, Hester Steyn ${ }^{3}$, Braam Van Wyk ${ }^{4}$, Benny Lemaire ${ }^{1}$, Erik Smets ${ }^{5}$, \\ Steven Dessein 6
}

1 Laboratory of Plant Systematics, Katholieke Universiteit Leuven, Leuven, Belgium, $\mathbf{2}$ Laboratory of Plant Growth and Development, University of Antwerp, Antwerp, Belgium, 3 South African National Biodiversity Institute, Pretoria, South Africa, 4 HGWJ Schweickerdt Herbarium, University of Pretoria, Pretoria, South Africa, 5 Netherlands Centre for Biodiversity Naturalis, Leiden University, Leiden, The Netherlands, 6 National Botanic Garden of Belgium, Meise, Belgium

\begin{abstract}
Background: South African plant species of the genera Fadogia, Pavetta and Vangueria (all belonging to Rubiaceae) are known to cause gousiekte (literally 'quick disease'), a fatal cardiotoxicosis of ruminants characterised by acute heart failure four to eight weeks after ingestion. Noteworthy is that all these plants harbour endophytes in their leaves: nodulating bacteria in specialized nodules in Pavetta and non-nodulating bacteria in the intercellular spaces between mesophyll cells in Fadogia and Vangueria.

Principal Findings: Isolation and analyses of these endophytes reveal the presence of Burkholderia bacteria in all the plant species implicated in gousiekte. Although the nodulating and non-nodulating bacteria belong to the same genus, they are phylogenetically not closely related and even fall in different bacterial clades. Pavetta harborii and Pavetta schumanniana have their own specific endophyte - Candidatus Burkholderia harborii and Candidatus Burkholderia schumanniana - while the non-nodulating bacteria found in the other gousiekte-inducing plants show high similarity to Burkholderia caledonica. In this group, the bacteria are host specific at population level. Investigation of gousiekte-inducing plants from other African countries resulted in the discovery of the same endophytes. Several other plants of the genera Afrocanthium, Canthium, Keetia, Psydrax, Pygmaeothamnus and Pyrostria were tested and were found to lack bacterial endophytes.

Conclusions: The discovery and identification of Burkholderia bacteria in gousiekte-inducing plants open new perspectives and opportunities for research not only into the cause of this economically important disease, but also into the evolution and functional significance of bacterial endosymbiosis in Rubiaceae. Other South African Rubiaceae that grow in the same area as the gousiekte-inducing plants were found to lack bacterial endophytes which suggests a link between bacteria and gousiekte. The same bacteria are consistently found in gousiekte-inducing plants from different regions indicating that these plants will also be toxic to ruminants in other African countries.
\end{abstract}

Citation: Verstraete B, Van Elst D, Steyn H, Van Wyk B, Lemaire B, et al. (2011) Endophytic Bacteria in Toxic South African Plants: Identification, Phylogeny and Possible Involvement in Gousiekte. PLoS ONE 6(4): e19265. doi:10.1371/journal.pone.0019265

Editor: Mark Alexander Webber, University of Birmingham, United Kingdom

Received January 20, 2011; Accepted March 24, 2011; Published April 26, 2011

Copyright: (C) 2011 Verstraete et al. This is an open-access article distributed under the terms of the Creative Commons Attribution License, which permits unrestricted use, distribution, and reproduction in any medium, provided the original author and source are credited.

Funding: This research was supported financially by the Fund for Scientific Research, Flanders (FWO, G.0343.09N), by the Katholieke Universiteit Leuven (OT/05/ 35) and by the King Leopold III Fund for Nature Exploration and Conservation. BV and BL hold a PhD research grant from the Institute for the Promotion of Innovation by Science and Technology in Flanders (IWT, no. 91158 and no. 71488) and DVE holds a PhD research grant from the Fund for Scientific Research, Flanders (FWO, no. 1.1.722.10.N.00). The funders had no role in study design, data collection and analysis, decision to publish, or preparation of the manuscript.

Competing Interests: The authors have declared that no competing interests exist.

* E-mail: brecht.verstraete@bio.kuleuven.be

\section{Introduction}

Some species of Rubiaceae from South Africa are known to cause a disease of domestic ruminants called gousiekte, an Afrikaans name literally translated as 'quick disease'. Gousiekte is one of the six most important plant poisonings in southern Africa. In 2008, the expected annual impact of mortalities from gousiekte on the livestock industry in South Africa was estimated at approximately $\mathrm{R} 9$ million in the case of cattle, and R5.2 million in the case of small stock [1]. Hitherto research into gousiekte was primarily carried out by veterinarians and focused on the aetiology and pathology of the disease. More recently toxicologists and chemists showed interest in the disease resulting in the isolation and chemical characterization of pavettamine, the compound claimed to be the cause of the cardiotoxicosis [2-4]. Gousiekte is a disease of ruminants characterized by acute heart failure without early warning signs 4-8 weeks after the initial ingestion of certain bacteriophilous Rubiaceae. Vangueria pygmaea (syn. Pachystigma pygmaeum) is the most important of these plants, followed in descending order of importance by Fadogia homblei, Pavetta harborii, Vangueria thamnus (syn. Pachystigma thamnus), Pavetta schumanniana and Vangueria latifolia (syn. Pachystigma latifolia) [5].

Significantly all gousiekte-inducing plants belong to Rubiaceae or coffee family, the fourth most species-rich flowering plant family with more than 13,000 species comprising about 611 genera [6]. It is a predominantly tropical and subtropical family but represen- 
tatives occur on all continents, except Antarctica. To date gousiekte has, with one exception (a case of African buffalo poisoning in Zimbabwe [7]), only been diagnosed in the northeastern part of South Africa and this coincides with the distribution of the toxic plants: the geographical ranges of all six gousiekte-inducing plants overlap in the former Transvaal region [5]. P. harborii, $V$. latifolia and $V$. thamnus are even restricted to that region, while $F$. homblei, $P$. schumanniana and $V$. pygmaea have a distribution range that extends further north indicating that gousiekte may in fact occur in other countries, but has not been diagnosed yet [8]. A wide variety of growth forms is present in Rubiaceae: woody shrubs are most common but small herbs, lianas and large rainforest trees are also encountered. Five of the gousiekte-inducing plants are geofructices (F. homblei, P. harborii, $V$. latifolia, $V$. pygmaea and $V$. thamnus) and one is a woody shrub or small tree ( $P$. schumanniana). Geofructices are plants with extensive or massive woody, perennial, underground stems and this enables the plants to sprout before the grass starts growing in spring, or in late summer when the grass withers [9]. During these two periods the green aboveground foliage and twigs of geofructices are readily consumed in large amounts by grazing livestock such as cattle and sheep [10].

The two Pavetta species that are involved in gousiekte have distinct bacterial nodules in their leaves. This type of leaf endosymbiosis is a rare and intimate interaction between plants and bacteria. Amongst flowering plants, Rubiaceae has the largest number of species with bacterial leaf nodules, these structures being present in three, distantly related genera, namely Pavetta, Psychotria and Sericanthe [11]. In Psychotria, the symbiotic cycle was shown to be obligate and cyclic: presence of the bacterial partner is required for host survival and the endophyte is retained within the host plant during all stages of its life cycle [12]. In the case of bacterial leaf nodules all previous attempts to identify the microbial symbiont based on morphological characterization have failed because its establishment in culture has not been successful as yet [13]. Recent molecular studies based on sequence analysis of 16S rDNA revealed that endophytes in Pavetta and Psychotria are host specific and belong to Burkholderia, a genus of highly diverse and adaptive proteobacteria [13-15].

A possible link between bacteria and gousiekte was postulated by Van Wyk et al. [16] following the discovery of bacterial symbionts in gousiekte-inducing members of Fadogia and Vangueria. Endophytic bacteria can be defined as bacteria that colonize the internal tissues of the plant without the host showing external signs of infection or other negative effects [17]. One possible advantage to bacteria in colonizing the internal tissues of a host plant is the presence of a uniform and protective environment. In return the endophyte can be beneficial to its host by promoting plant growth or by preventing infection by phytopathogenic organisms [18].

Before we can answer the question whether these endophytic bacteria and their host plant collaborate in causing gousiekte, further fundamental knowledge about occurrence and identity of the endophytes is essential. Our principal objective is not to give a conclusive causality but to identify the bacterial endophytes and to elucidate their phylogenetic context. Adding several related Rubiaceae species that grow in the same area will help determine whether endophytic bacteria are limited to the gousiekte-inducing plants. If endophytic bacteria are only found in the species that cause gousiekte it might indicate a possible involvement of the bacteria in gousiekte. It should be noted however, that a definitive causation cannot be proved from association studies alone. Nevertheless, identification of the different actors is the first step in finding a possible remediation of gousiekte.

\section{Results}

Using a cultivation-independent approach, bacterial endophytes are found in all of the six gousiekte-inducing Rubiaceae species. The identification of the bacteria was performed using the standard method of comparing the sequence similarity of the $16 \mathrm{~S}$ rDNA region [19]. Additional support for the identity is obtained through a combined phylogenetic analysis of the three molecular markers 16S, gyrB and recA.

The two species of Pavetta involved in gousiekte both have visible bacterial nodules in their leaves. The endophyte of $P$. schumanniana specimens from D.R.Congo and Zambia have already been identified and described as Candidatus Burkholderia schumanniana [18]. All DNA sequences of the endophytes in South African $P$. schumanniana are identical to the Congolese and Zambian ones and are thus considered as the same species. Several clones were obtained for the $16 \mathrm{~S} \mathrm{rDNA}$ region of $P$. harborii and only one unique sequence emerged, which indicates the presence of only one bacterium species. Different replicas of P. harborii were tested and the bacterial 16S rDNA sequences for all specimens are identical. BLAST analysis of the $16 \mathrm{~S}$ rDNA sequences of the endophytes confirmed the bacterial identity as Burkholderia. It is closely related to Candidatus Burkholderia schumanniana and their 16S rDNA sequences have a difference of $1 \%$.

Leaves of $F$. homblei, $V$. latifolia, $V$. pygmaea and $V$. thamnus do not have dark spots (nodules) on their leaf blades. Cultivationindependent analysis using sequences of $16 \mathrm{~S}$ rDNA revealed the presence of non-nodulating endophytic bacteria in these species. The cloning experiments resulted in several clones of all four species indicating that only one endophyte per plant species is present. Several replicas from different geographic locations were tested for all species. Gousiekte plants originating from other African countries (D.R.Congo and Zambia) harbour the same bacteria as the South African specimens. The 16S rDNA regions of the endophytes of the four gousiekte-inducing species are $99.9 \%$ homologous and BLAST searches revealed that the sequences are almost identical (99.9\%) to Burkholderia caledonica.

Besides 16S rDNA, two widely used housekeeping genes ( $\mathrm{gyr} B$ and $\operatorname{rec} A$ ) were added for phylogenetic analysis. Because all $16 \mathrm{~S}$ clones from the cloning experiments are identical, only one sequence per plant specimen was used to facilitate the phylogenetic analysis. The different geographic replicas were retained in the analysis. The combined dataset of the three genetic markers comprised the sequences of three outgroup species, 38 Burkholderia species, five nodulating endophytes and the endophytes of 28 gousiekte-inducing plants. Replicates of the bacteria found in $P$. harborii are identical and are related to Candidatus Burkholderia schumanniana, the endophyte of the gousiekte-inducing plant $P$. schumanniana. The non-nodulating endophytes of $F$. homblei, $V$. latifolia, $V$. pygmaea and $V$. thamnus cluster together with $B$. caledonica in a strongly supported clade (Figure 1). Although there is almost no variation in the $16 \mathrm{~S}$ rDNA sequences, the endophytes of the individual gousiekte-inducing species group together because of minimal differences in $\operatorname{gyr} B$ and $r e c A$ sequences.

In one of the species, $F$. homblei, we succeeded in isolating and cultivating the endophytic bacteria. The isolation procedures on leaves yielded only one bacterium species. These isolates were proven to be closely related to $B$. caledonica by the DNA analysis and they fall in the same clade as the endophytes identified by the cultivation-independent analysis (Figure 1). Both types of culture medium (LB and PCAT) gave consistent results.

Twenty-four Rubiaceae plants, which grow in the same area as the gousiekte-inducing plants but are not implicated in the disease, were investigated for the presence of bacterial endophytes. They 


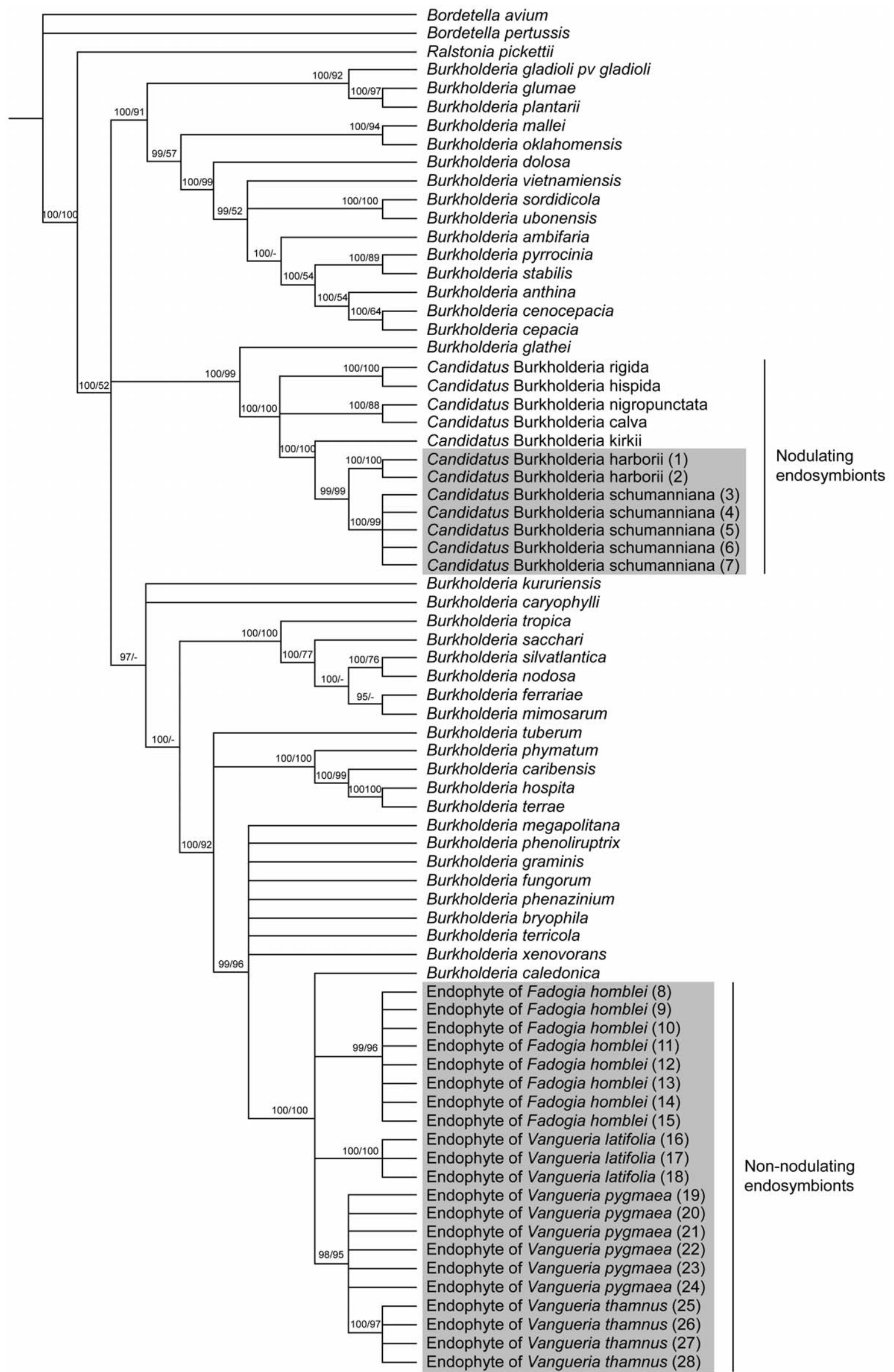


Figure 1. Phylogenetic relationships within the bacterial genus Burkholderia. The tree is based on $16 \mathrm{~S}$ rDNA, gyrB and recA data. Numbers on branches represent Bayesian posterior probabilities and maximum parsimony bootstrap support. Gousiekte-inducing plants are indicated in grey boxes. Numbers between brackets correspond to the numbers in Table S1. doi:10.1371/journal.pone.0019265.g001

belong to 14 species in the genera Afrocanthium, Canthium, Keetia, Psydrax, Pygmaeothamnus and Pyrostria that are part of Vanguerieae, the tribe containing four of the gousiekte-inducing plants. There are no visual bacterial nodules present in the leaves of any of the specimens investigated. Despite different biological and technical replicas, none of the species is shown to have endophytic bacteria inside their leaves.

\section{Discussion}

Nodulating bacterial leaf endosymbiosis has been the subject of several scientific studies resulting in the identification of the endophytes as members of the genus Burkholderia [16-18]. This genus of $\beta$-proteobacteria has also been found to nodulate the plant roots of legumes [20]. The endophyte of the gousiekte plant $P$. schumanniana has already been identified as Candidatus Burkholderia schumanniana and is proven to be host specific [18].

We showed that the nodulating endophyte of $P$. harborii is closely related to Candidatus Burkholderia schumanniana (Figure 1), but the DNA sequences are slightly different. Based on the $99 \% 16 \mathrm{~S}$ rDNA sequence similarity to delineate bacterial species [19] and because the endophytes of other Pavetta species are host specific [18], we conclude that the endophyte in $P$. harborii is a new species. $P$. schumanniana and $P$. harborii are morphologically closely related, hence the close similarity of their endophytes is to be expected. $P$. harborii, however, is a geofructex, whereas $P$. schumanniana is a proper shrub or small tree; their geographical ranges are also mutually exclusive. Cultivation of the endophytes of Pavetta has not been successful yet [16] and because uncultured organisms should be recorded under the provisional status Candidatus [21], we propose the name 'Candidatus Burkholderia harborii' for this taxon.

This is the first molecular investigation of the endophytes of gousiekte plants and it provides unequivocal evidence that members of Fadogia and Vangueria, unlike in the case of Pavetta, do not have visible bacterial nodules; instead there are nonnodulating bacteria present in the leaves. This confirms earlier observations based on light and electron microscopy [11].

The 16S rDNA sequence similarity between the non-nodulating bacteria found in four gousiekte plants and the nodulating endophytes of the two Pavetta species is about 96\%, which indicates that they are not closely related. This conclusion is also reached when observing the relationships on the phylogenetic tree, which is based on three molecular markers (Figure 1). The nodulating and non-nodulating endophytes belong to the same genus Burkholderia, but they fall into different well-supported clades. This indicates that both lineages of bacteria independently developed the strategy to incorporate themselves in the leaves of Rubiaceae species. The only difference is that the endophytes of Pavetta and Psychotria are confined to discrete nodules (visible to the naked eye), while the endophytes of Fadogia and Vangueria remain diffusely distributed in the intercellular spaces among cells in the leaf tissues [11]. The phylogenetic tree indicates that the nonnodulating endophytes in Fadogia and Vangueria are very similar to Burkholderia caledonica (Figure 1). In fact the 16S rDNA sequences are $99.9 \%$ identical. Several clones per plant species and specimens from different geographic locations gave consistent results.

B. caledonica is a soil bacterium previously isolated from the rhizosphere of grapevine (Vitis sp.) and sugarcane (Saccharum officinarum) [22]. Noteworthy is that some of the closely related Burkholderia species are endophytes themselves (e.g. B. bryophila is an endosymbiont of moss, [23]) while others are soil bacteria that are in close contact with the root systems of plants (e.g. B. xenovorans is found in the rhizosphere of the coffee plant, [24]).

Although the $16 \mathrm{~S}$ rDNA regions are identical, the $\operatorname{gyr} B$ and $\operatorname{rec} A$ sequences reveal that the endophytes of each plant species form separate clades, indicating host specificity of the bacteria at population level. This means that different populations of the same bacterial species are found in different plant species. Based on this, it can be hypothesized that the interaction between bacteria and plants in this lineage of Rubiaceae recently evolved and that the bacteria are still undergoing speciation.

Until now all attempts to cultivate the nodulating Burkholderia of Psychotria have been unsuccessful [16]. In the present study, however, we were able to grow the non-nodulating endophyte of $F$. homblei on agar plates. Only one bacterium species emerged and its identification corroborated the results of the cultivationindependent analysis. Significantly, one of the tested $F$. homblei plants was grown from seeds collected in the wild. It has been suggested that nodulating bacteria in species of Psychotria could similarly be transferred to the next plant generation through the seeds [15]. The fact that our cultivated $F$. homblei has the same endophyte as the wild specimens may point to the presence of bacteria in the seeds. This would explain the occurrence of distinct populations of endophytes in the different gousiekte-inducing plants as shown by the phylogenetic analysis (Figure 1).

Since almost a century, veterinarians have searched for the cause of gousiekte and this resulted in the denotation of six toxic plants: F. homblei, V. latifolia, $V$. pygmaea, $V$. thamnus, $P$. harborii and $P$. schumanniana [5]. We already pointed out that they all of these belong to Rubiaceae, more in particular to the subfamily Ixoroideae. Within the subfamily the species are not closely related: Fadogia and Vangueria are two genera of the tribe Vanguerieae, while Pavetta is a member of the tribe Pavetteae (Figure 2). Endophytic bacteria of the genus Burkholderia contained in specialized nodules are already known for the Pavetteae but this study is the first to establish the identity of the non-nodulating bacteria in the Vanguerieae. In South Africa many toxic plants are found causing a wide range of plant poisonings and mycotoxicoses [8], but why only six plants are responsible for gousiekte remains enigmatic. It is likely that other toxic rubiaceous plants are ignored in areas where gousiekte plants have already been identified [11]. To investigate whether the endophytic bacteria are limited to the gousiekte plants we added 24 specimens to our sampling (Table S2). These belong to 14 species that overlap in distribution area with the gousiekte-inducing plants and that are abundantly present. The genera involved are Afrocanthium, Canthium, Keetia, Psydrax, Pygmaeothamnus and Pyrostria and these are all part of Vanguerieae, the tribe containing four of the gousiekte-inducing plants. We could not detect visible bacterial nodules in their leaves and after careful molecular investigation, no endophytic bacteria could be found. Pygmaeothamnus zeyheri and P. chamaedendrum are very similar to $V$. pygmaea and $V$. thamnus and they often occur next to each other in the field. We tested these two plants several times and no bacterial DNA was amplified. Particularly noteworthy is that these two plants were tested for gousiekte by South African veterinarians but were found to be non-toxic [25]. These findings could support a possible role of the bacteria in causing gousiekte. 


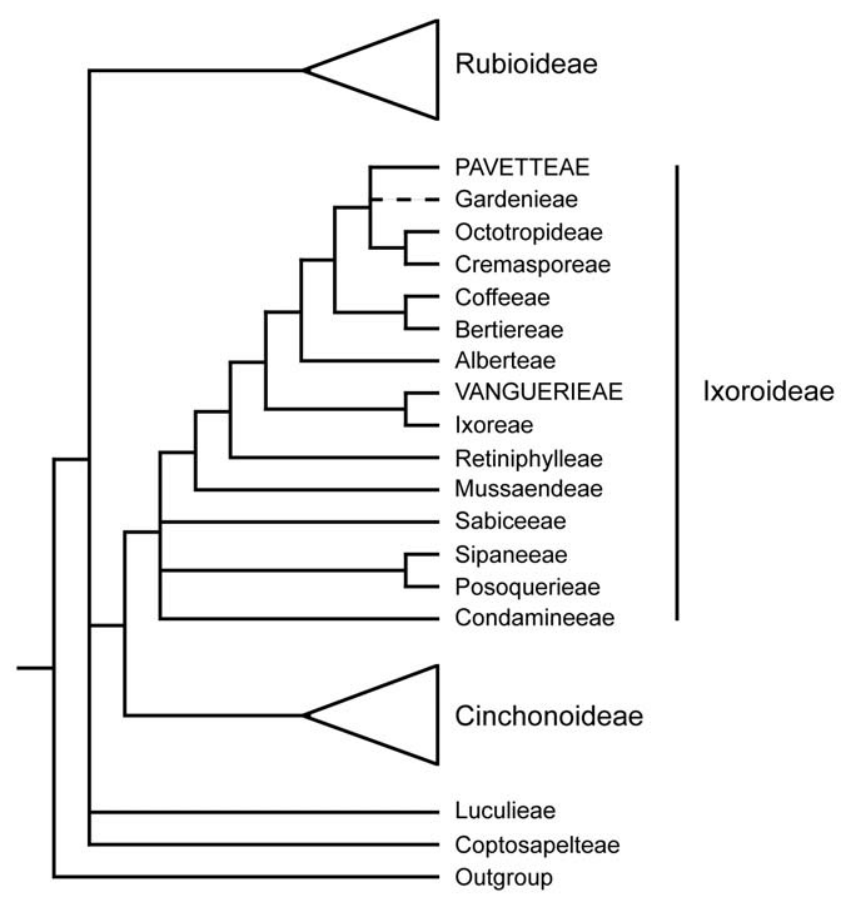

Figure 2. Adapted phylogenetic tree of the plant family Rubiaceae [36]. The gousiekte-inducing plants are part of the subfamily Ixoroideae, one of the three subfamilies in Rubiaceae. Nevertheless, they are not closely related as they belong to different tribes: Fadogia and Vangueria belong to Vanguerieae, while Pavetta belongs to Pavetteae. The respective tribes are indicated in capital letters.

doi:10.1371/journal.pone.0019265.g002

Geographically, gousiekte occurs in the northeastern part of South Africa and most of the outbreaks happen in the former Transvaal region. Nevertheless, it is presumed that it may in fact occur in other countries [8]. Only very recently, gousiekte has been diagnosed in wild African buffalo from Zimbabwe after eating $P$. schumanniana [7]. This indicates a wider distribution for the disease and it also shows that not only domestic livestock can be affected. In our study we included some gousiekte plants from D.R.Congo and Zambia to test whether the presence of endophytic bacteria is geographically limited. This is not the case since we consistently found the same bacteria in plants from different regions. If Burkholderia bacteria play a role in causing gousiekte, it is highly probable that the same plants growing in other African countries will also be toxic to ruminants.

The discovery and identification of Burkholderia bacteria in all investigated gousiekte-inducing plants open new perspectives and opportunities for research into the cause of the disease. A question that still remains unanswered is the origin of the putative toxin: are the plants or the endophytic Burkholderia, or perhaps both together, responsible for the production of pavettamine? It is well known that bacterial endosymbionts can be important in the production of toxic metabolites in plants [26-27]. It has, for example, been shown that endosymbiotic Burkholderia bacteria produce rhizoxin, a phytotoxin, in members of the plant pathogenic fungus Rhizopus [28]. Ongoing research into the cultured endophytes of $F$. homblei holds great promise in answering this question and thus giving perspective in a possible remediation of gousiekte.

In summary, toxic gousiekte-inducing plants are shown to have nodulating or non-nodulating Burkholderia bacteria. Host plant specificity at population level indicates a recent interaction and predicts ongoing speciation. Other South African Rubiaceae that grow in the same area as the gousiekte-inducing plants were tested and found to lack bacterial endophytes which suggests a link between bacteria and gousiekte. Discovery of the same endophytes in non South African gousiekte-inducing plants points to a wider occurrence of the disease. Our results not only shed new light on the evolution of bacterial endosymbiosis in Rubiaceae but also open new perspectives for further research into the functional significance of this phenomenon in the family, as well as its possible involvement in the formation of the gousiekte-causing toxin.

\section{Description of 'Candidatus Burkholderia harborii'}

'Candidatus Burkholderia harborii' (harborii, from the specific epithet of the host plant, Pavetta harborii, which was named after its discoverer Cyril Cecil Harbor (1883-1940)). [( $\beta$-Proteobacteria, genus Burkholderia); NC; G-; R; NAS (GenBank accession numbers JF265202, JF265179, JF265225), oligonucleotide sequence complementary to unique region of $16 \mathrm{~S}$ rDNA 5'-TCTGTTAAGACGGGTGTGAAATCGCTGGGCTC-3', oligonucleotide sequence complementary to unique region of $\operatorname{gyr} B$ gene $5^{\prime}$ TAGGGAGAACGGCGGCACTGAGGTGCACTTCG-3'， oligonucleotide sequence complementary to unique region of $\mathrm{rec} A$ gene 5'-CACGCTGCAGGTGATTGCTGAGATGCAGAAGC$3^{\prime}$; S (Pavetta harborii, leaf)]. Verstraete et al., this study.

\section{Materials and Methods}

Most of the plant material was collected during a field expedition in South Africa but additional samples were obtained from the National Botanic Garden of Belgium and the South African National Biodiversity Institute. Detailed information on the six gousiekte-inducing species and their respective bacterial endophyte can be found in Table S1. Herbarium vouchers for the other Rubiaceae species that are investigated in this study are mentioned in Table S2.

Before extraction of the bacterial DNA the silica-dried leaves were rinsed using $70 \%$ ethanol to avoid bacterial contamination. Extraction of the DNA was performed using the E.Z.N.A. ${ }^{\text {TM }} \mathrm{HP}$ Plant DNA Mini Kit (Omega Bio-Tek).

Initially, PCR amplification of bacterial 16S rDNA was done with universal primers 16SB and 16SE [17]. A second more specific reverse primer $16 \mathrm{~S} 2$ was also used to avoid amplification of chloroplast homologues [18]. For the amplification of DNA gyrase, subunit B $(\operatorname{gyr} B)$ and recombinase A $(r e c A)$, primers were used as proposed by Spilker et al. [29]. The polymerase chain reactions (PCR) were run on a GeneAmp PCR System 9700 (Applied Biosystems, Foster City, California, USA) under a temperature profile of $94^{\circ} \mathrm{C}$ for $2 \mathrm{~min}$ followed by 30 cycles of $94^{\circ} \mathrm{C}$ for $45 \mathrm{sec}, 55^{\circ} \mathrm{C}(16 \mathrm{~S} \mathrm{rDNA})$ or $58^{\circ} \mathrm{C}$ (gyrB and recA) for $60 \mathrm{sec}$, and $72^{\circ} \mathrm{C}$ for $90 \mathrm{sec}$. The PCR products of $16 \mathrm{~S}$ rDNA were ligated into pGEM-T vector (Promega), according to the manufacturer's instructions, and transformed into JM109 E. coli by heat shock. Plasmid purification was obtained by using a PureYield $^{\text {TM }}$ Plasmid Miniprep System (Promega). Purified plasmid products were sent to Macrogen for sequencing (Macrogen Inc, Seoul, Korea).

The sequences were assembled and edited using Geneious 5.3 [30]. All new DNA data are deposited in GenBank and the accession numbers can be found in Table S1. Related bacterial sequences of Burkholderia were obtained from the BCCM/LMG Bacteria Collection (Belgian Co-ordinated Collections of Microorganisms/Laboratory of Microbiology, Ghent University, http:/ / bccm.belspo.be) and GenBank. Detailed information on these 
sequences can be found in the supplementary table $\mathrm{S} 1$ of Lemaire et al. [18]. A preliminary sequence alignment was performed in Geneious using a plugin for Muscle [31] followed by manual adjustments resulting in an unequivocal alignment. Phylogenetic trees were estimated using Bayesian Inference and Maximum Parsimony. Bayesian analysis was inferred using MrBayes 3.1 [32], running four Markov chains sampling every 100 generations for three million generations. A general time reversible model of DNA substitution with gamma-distributed rate variation across invariant sites was used $(\mathrm{GTR}+\mathrm{I}+\mathrm{G})$. This model was chosen by performing hierarchical likelihood-ratio tests in MrModeltest v.3.06 [33]. Maximum parsimony analyses were conducted using Paup* v.4.0b10a [34]. Heuristic searches were conducted with TBR branch swapping on 10,000 random addition replicates, with five trees held at each step. Non-parametric bootstrap analysis was carried out to calculate the relative support for individual clades found in the parsimony analysis. For each of 1,000 bootstrap replicates, a heuristic search was conducted with identical settings as in the original heuristic analysis.

For growing the endophytic bacteria of $F$. homblei in culture, young leaves were collected. Leaf surfaces were sterilized with $80 \%$ ethanol for $5 \mathrm{~min}$ followed by $10 \mathrm{~min}$ in sodium hypochlorite $(1 \%)$ and finally washed with sterile distilled water. Sterility was checked by placing sterilized leaf fragments in liquid LB medium. For endophyte extraction, sterile leaves were crushed in autoclaved mortars with $0.85 \%$ sodium chloride as buffer. The resulting fluid was spread on LB and PCAT agar plates [35]. Single colonies were picked out and grown in liquid medium for DNA analysis. Bacterial DNA was extracted using the DNeasy Blood \& Tissue kit (Qiagen GmbH). Amplification and sequencing

\section{References}

1. Prozesky L (2008) A study of the pathology and pathogenesis of myocardial lesions in gousiekte, a cardiotoxicosis of ruminants. $\mathrm{PhD}$ Thesis. University of Pretoria, Department of Paraclinical Sciences.

2. Bode ML, Gates PJ, Gebretnsae SY, Vleggaar R (2010) Structure elucidation and stereoselective total synthesis of pavettamine, the causal agent of gousiekte. Tetrahedron 66: 2026-2036.

3. Ellis CE, Naicker D, Basson KM, Botha CJ, Meintjes RA, et al. (2010a) Damage to some contractile and cytoskeleton proteins of the sarcomere in rat neonatal cardiomyocytes after exposure to pavetamine. Toxicon 55: 1071-1079.

4. Ellis CE, Naicker D, Basson KM, Botha CJ, Meintjes RA, et al. (2010b) A fluorescent investigation of subcellular damage in H9c2 cells caused by pavetamine, a novel polyamine. Toxicology in Vitro 24: 1258-1265.

5. Kellerman TS, Coetzer JAW, Naudé TW, Botha CJ (2005) Plant poisonings and mycotoxicoses of livestock in southern Africa. Cape Town: Oxford University Press. $215 \mathrm{p}$

6. Davis AP, Govaerts R, Bridson DM, Ruhsam M, Moat J, et al. (2009) A global assessment of distribution, diversity, endemism, and taxonomic effort in the Rubiaceae. Ann Miss Bot Gard 96: 69-78.

7. Lawrence JA, Foggin CM, Prozesky L (2010) Gousiekte in African buffalo (Syncerus caffer). J S Afr Vet Assoc 81: 170-171.

8. Naudé T, Kellerman T, Coetzer J (1996) Plant poisonings and mycotoxicoses as constraints in livestock production in East Africa: the southern African experience. J S Afr Vet Assoc 67: 8-11.

9. White F (1976) The underground forests of Africa: a preliminary review. The Gardens' Bulletin Singapore 29: 55-71.

10. Botha CJ, Penrith M-L (2008) Poisonous plants of veterinary and human importance in southern Africa. J Ethnopharm 119: 549-558.

11. Robbrecht E (1988) Tropical woody Rubiaceae. Opera Bot Belg 1: 1-271.

12. Miller IM (1990) Bacterial leaf nodule symbiosis. In: Callow JA, ed. Advances in Botanical Research. Vol. 17. San Diego: Academic Press. pp 163-234.

13. Van Oevelen S, De Wachter R, Robbrecht E, Prinsen E (2004) 'Candidatus Burkholderia calva' and 'Candidatus Burkholderia nigropunctata' as leaf gall endosymbionts of African Psychotria. Int J Syst Sci 54: 2237-2239.

14. Van Oevelen S, De Wachter R, Vandamme P, Robbrecht E, Prinsen E (2002) Identification of the bacterial endosymbionts in leaf galls of Psychotria (Rubiaceae, angiosperms) and proposal of 'Candidatus Burkholderia kirkii' sp. nov. Int J Syst Sci 52: 2023-2027.

15. Lemaire B, Van Oevelen S, De Block P, Verstraete B, Smets E, et al. (2011) Identification of the bacterial endosymbionts in leaf nodules of Pavetta (Rubiaceae). Int J Syst Sci doi:ijs.0.028019-0. of the selected bacterial DNA markers was carried out as stated above.

\section{Supporting Information}

Table S1 Detailed information on the endophytes of the six gousiekte-inducing plants. List of the investigated endophytes with origin, host plant voucher specimen and GenBank accession numbers. Herbarium vouchers are deposited at BR or PRE and acquisition numbers refer to the living collection of the National Botanic Garden of Belgium (NBGB). The endophytes cultivated on agar plates are indicated with an asterisk.

(DOC)

Table S2 Detailed information on the investigated Rubiaceae plants that are not linked with gousiekte. None of the here listed specimens has endophytic bacteria inside their leaves.

(DOC)

\section{Acknowledgments}

The authors would like to thank Elsa Van Wyk for assistance with the obtainment of literature on gousiekte. Norbert Hahn is acknowledged for his help during fieldwork.

\section{Author Contributions}

Conceived and designed the experiments: BV DVE BL ES SD. Performed the experiments: BV DVE. Analyzed the data: BV DVE. Contributed reagents/materials/analysis tools: BV DVE HS BVW BL SD. Wrote the paper: BV.

16. Van Wyk AE, Kok PDF, Van Bers NL, van der Merwe CF (1990) Nonpathological bacterial symbiosis in Pachystigma and Fadogia (Rubiaceae): its evolutionary significance and possible involvement in the aetiology of gousiekte in domestic ruminants. S Afr J Sci 86: 93-96.

17. Ryan RP, Germaine K, Franks A, Ryan DJ, Dowling DN (2008) Bacterial endophytes: recent developments and applications. FEMS Microbiol Lett 278: $1-9$.

18. Compant S, Duffy B, Nowak J, Clément C, Ait Barka E (2005) Use of plant growth-promoting bacteria of biocontrol of plant disease: principles, mechanisms of action, and future prospects. Appl Environ Microb 71: 49514959 .

19. Stackebrandt E, Ebers J (2006) Taxonomic parameters revisited: tarnished gold standards. Microbiology Today November. pp 152-155.

20. Moulin L, Munive A, Dreyfus B, Boivin-Masson C (2001) Nodulation of legumes by members of the beta-subclass of Proteobacteria. Nature 411: 948-950.

21. Murray RGE, Stackebrandt E (1995) Taxonomic note: implementation of the provisional status Candidatus for incompletely described prokaryotes. Int J Syst Bacteriol 45: 186-187.

22. Compant S, Nowak J, Coenye T, Glément G, Ait Barka E (2008) Diversity and occurrence of Burkholderia spp. in the natural environment. FEMS Microbiol Rev 32: 607-626.

23. Vandamme PA, Opelt K, Knöchel N, Berg D, Schönmann S, et al. (2007) Burkholderia bryophila sp. nov. and Burkholderia megapolitana sp. nov., mossassociated species with antifungal and plant-growth-promoting properties. Int J Syst Sci 57: 2228-2235.

24. Estrada-de los Santos P, Bustillos-Cristales R, Caballero-Mellado J (2001) Burkholderia, a genus rich in plant-associated nitrogen fixers with wide environmental and geographic distribution. Appl Environ Microbiol 67: 2790-2798.

25. Codd LE (1961) Notes on poisonous plants, with special reference to the gousiekte problem. J S Afr Biol Soc 2: 8-17.

26. Piel J (2004) Metabolites from symbiotic bacteria. Nat Prod Rep 21: 519-538.

27. Piel J (2009) Metabolites from symbiotic bacteria. Nat Prod Rep 26: 338-362.

28. Partida-Martinez LP, Hertweck G (2005) Pathogenic fungus harbours endosymbiotic bacteria for toxin production. Nature 437: 884-888.

29. Spilker T, Baldwin A, Bumford A, Dowson CG, Mahenthiralingam E, et al. (2009) Expanded multilocus sequence typing for Burkholderia species. J Clin Microbiol 47: 2607-2610.

30. Drummond AJ, Ashton B, Buxton S, Cheung M, Cooper A, et al. (2010) Geneious v5.3. Available: www.geneious.com. 
31. Edgar RC (2004) MUSCLE: multiple sequence alignment with high accuracy and high throughput. Nucl Acids Res 32: 1792-1797.

32. Ronquist F, Huelsenbeck JP (2003) MrBayes 3: Bayesian phylogenetic inference under mixed models. Bioinformatics 19: 1572-1574.

33. Posada D, Crandall KA (1998) Modeltest: testing the model of DNA substitution. Bioinformatics 14: 817-818.
34. Swoffort DL (2002) PAUP*: phylogenetic analysis using parsimony (*and other methods), version 4. Sunderland: Sinauer.

35. Burbage DA, Sasser M (1982) A medium selective for Pseudomonas cepacia. Phytopathology 72: 706 .

36. Bremer B, Eriksson T (2009) Time tree of Rubiaceae: phylogeny and dating the family, subfamilies, and tribes. Int J Plant Sci 170: 766-793. 